\title{
INEQUALITIES OF THE EDMUNDSON-LAH-RIBARIČ TYPE FOR SELFADJOINT OPERATORS IN HILBERT SPACES
}

\author{
ROZARIJA MiKIĆ AND JOSIP PEČARIĆ
}

\begin{abstract}
By exploiting some scalar inequalities obtained via Hermite's interpolating polynomial, we will obtain lower and upper bounds for the difference in Jensen's inequality and in the Edmundson-Lah-Ribarič inequality for selfadjoint operators in Hilbert space that hold for the class of $n$-convex functions. As an application, main results are applied to quasi-arithmetic operator means, with a particular emphasis to power operator means.
\end{abstract}

Mathematics subject classification (2010): 46C05, 47A63, 26A51.

Keywords and phrases: Jensen inequality, Edmundson-Lah-Ribarič inequality, scalar product, $n$-convex functions, divided differences, operator means.

\section{REFERENCES}

[1] R. P. Agarwal And P. J. Y. Wong, Error Inequalities in Polynomial Interpolation and Their Applications, Kluwer Academic Publishers, Dordrecht, Boston, London, 1993.

[2] D. ChOI, M. KRnić AND J. PeČARIĆ, More accurate classes of Jensen-type inequalities for convex and operator convex functions, Math. Inequal. Appl., 21, 2 (2018), 301-321.

[3] S. S. DRAGOMIR, Some reverses of the Jensen inequality for the functions of selfadjoint operators in Hilbert spaces, Preprint RGMIA Res. Rep. Coll., 11, e (2008).

[4] M. Fujit, J. MićIĆ Hot, J. E. PeČARIĆ And Y. SEO, Recent Developments of Mond-Pečarić Method in Operator Inequalities. Inequalities for Bounded, Selfadjoint Operators on a Hilbert Space II, Element, Zagreb, 2012.

[5] T. Furuta, J. Mićić Hot, J. E. PeČArić And Y. Seo, Mond-Pečarić Method in Operator Inequalities. Inequalities for Bounded, Selfadjoint Operators on a Hilbert Space, Element, Zagreb, 2005.

[6] R. JAKŠIĆ AND J. PEČARIĆ, Converses of convex inequalities in Hilbert space, Rend. Circ. Mat. Palermo, 63, 1 (2014), 1-9.

[7] R. JAKŠIĆ AND J. PEČARIĆ, On some new converses of convex inequalities in Hilbert space, Banach J. Math Anal., 9, 2 (2015), 63-82.

[8] J. Mićić Hot And Y. SEO, An interpolation of Jensen's inequality and its applications to mean inequalities, J. Math. Inequal., 12, 2 (2018), 303-313.

[9] R. Mikić, Đ. PEČARIĆ AND J. PEČARIĆ, Inequalities of the Edmundson-Lah-Ribarič type for nconvex functions with application, arXiv:1809.08813

[10] D. S. Mitrinović, J. E. PeČArić And A. M. Fink, Classical and New Inequalities in Analysis, Cluwer Academic, 1993.

[11] B. Mond And J. E. PeČArić, Convex inequalities in Hilbert space, Houston J. Math., 19, (1993), 405-420.

[12] J. E. PeČarić, F. Proschan And Y. L. Tong, Convex functions, Partial orderings and statistical applications, Academic Press Inc., San Diego 1992. 